\title{
Role of Cadmium and Lead Tolerant Pseudomonas aeruginosa in Seedling Germination of Rice (Oryza sativa L.)
}

Soumitra Nath ${ }^{1 *}$, Bibhas Deb ${ }^{2}$, Indu Sharma ${ }^{3}$ and Piyush Pandey ${ }^{3}$

${ }^{1}$ Bioinformatics Centre, Gurucharan College, Silchar, India

${ }^{2}$ Department of Botany Gurucharan College, Silchar, India

${ }^{3}$ Department of Microbiology, Assam University, Silchar, India

\begin{abstract}
In the present study, cadmium and lead tolerant bacteria were isolated from contaminated crop field nearby industrial sites, garage and petrol pumps of Cachar District of Assam, India. Bacterial isolates were characterized on the basis of morphological, physiological, biochemical characteristics and 16S rDNA gene sequencing. In presence of cadmium, Pseudomonas aeruginosa SN1 and Pseudomonas aeruginosa SN3 showed the highest MIC for cadmium and lead. These two isolates were taken under consideration for pot experimental studies.

After 20 days of seedling inoculation in Cd treated soil and application of $P$. aeruginosa SN1, it has been observed that rice plant (Oryza sativa L.) attains $10.1 \%$ (at $20 \mathrm{mg} / \mathrm{kg} \mathrm{Cd}$ ) and $18.6 \%$ (at $50 \mathrm{mg} / \mathrm{kg} \mathrm{Cd}$ ) increased shoot growth as compared to control pots without bacterial inoculation. $P$. aeruginosa SN1 and $P$. aeruginosa SN3, showed significant result at $20 \mathrm{mg} / \mathrm{kg}$ of lead in soil but, failed to show any significant response at $50 \mathrm{mg} / \mathrm{kg}$ of lead in soil. Overall study demonstrated that $P$. aeruginosa SN1 and $P$. aeruginosa SN3 could remediate cadmium and lead contaminated soil at concentration below $20 \mathrm{mg} / \mathrm{kg}$, thus dedicating sites which are set aside for long term agricultural purpose.
\end{abstract}

Keywords: Minimum inhibitory concentration; Oryza sativa L.; Cadmium; Lead; Pseudomonas aeruginosa

\section{Introduction}

Excessive accumulation of heavy metals in agricultural soils through wastewater irrigation, results in soil contamination that lead to elevated heavy metal uptake by crops, and thus affect food quality and safety [1]. Heavy metal accumulation in soils and plants is of increasing concern because of the potential human health risks. Heavy metals are included in the main category of environmental pollutants as they can remain in the environment for long periods; their accumulation is potentially hazardous to humans, animals and plants [2].

Metals are directly and/or indirectly involved in all aspects of microbial growth, metabolism and differentiation [3]. Metals and their compounds interact with microbes in various ways depending on the metal species, organism and environment, while structural components and metabolic activity also influence metal speciation and therefore solubility, mobility, bioavailability and toxicity [3-6]. Many metals are essential for life, e.g. $\mathrm{Na}, \mathrm{K}, \mathrm{Cu}, \mathrm{Zn}, \mathrm{Co}, \mathrm{Ca}, \mathrm{Mg}, \mathrm{Mn}$ and $\mathrm{Fe}$, but all can exert toxicity when present above certain threshold concentrations. Other metals, e.g. $\mathrm{Cs}, \mathrm{Al}, \mathrm{Cd}, \mathrm{Hg}$ and $\mathrm{Pb}$, have no known essential metabolic functions but all can be accumulated. Microbes are intimately associated with the biogeochemical cycling of metals, and associated elements, where their activities can result in mobilization and immobilization depending on the mechanism involved and the microenvironment where the organism(s) are located [5-8].

Some reports have shown that indigenous microbes and plantmicrobe symbionts tolerate high heavy metal concentrations in different ways and may play a significant role in the restoration of contaminated soil $[9,10]$. The objectives of the present study are as follows:

1. Isolation and identification of cadmium and lead tolerant bacteria from contaminated crop field

2. Pot experimental studies to evaluate the effectiveness of isolated strains in seedling germination of Orya sativa at different concentration of $\mathrm{Cd}$ and $\mathrm{Pb}$ in soil

\section{Materials and Methods}

\section{Collection of soil sample and selective isolation of Pseudomonas spp.}

Soil samples were first collected from contaminated crop fields nearby paper industry, garage and petrol pumps of Cachar District of Assam, India. Soil samples were collected in sterilized polythene bags and immediately bought to the laboratory. Selective isolation of Pseudomonas spp. was performed by spreading the samples on Pseudomonas Isolation Agar (PIA) media. Individual distinct colonies were further undergone repeated sub-culturing and were identified by their morphological and biochemical characteristics [11].

\section{Identification by $16 \mathrm{~S}$ rDNA sequencing}

Genomic DNA was extracted from bacterial isolates as described by Sambrook et al., [12] and amplification of $16 \mathrm{~S}$ rDNA gene was performed. The PCR procedure consisted of preparation of master mix for PCR containing 10X Taq buffer A $(1 \mathrm{X}), 10 \mathrm{mM} \mathrm{\textrm {MCl } _ { 2 }}(1.5 \mu \mathrm{l})$, $10 \mathrm{mM}$ dNTP mix $(1.0 \mu \mathrm{l})$ and sterile distilled water. The gene fragment was amplified using $20 \mathrm{ng}$ of the DNA, $100 \mathrm{ng}$ of each primer (forward and reverse) and Taq polymerase $(3 \mathrm{U})$. The reaction volume was adjusted to $50 \mu \mathrm{l}$ using sterile distilled water. The $\sim 1.4 \mathrm{~kb}$-PCR products of $16 \mathrm{~S}$ rDNA genes were used for DNA sequencing. After sequencing,

*Corresponding author: Soumitra Nath, Bioinformatics Centre, Gurucharan College, Silchar, India, Tel: 03842-264504; E-mail: nath.soumitra1@gmail.com

Received March 22, 2014; Accepted May 05, 2014; Published May 08, 2014

Citation: Nath S, Deb B, Sharma I, Pandey P (2014) Role of Cadmium and Lead Tolerant Pseudomonas aeruginosa in Seedling Germination of Rice (Oryza sativa L.). J Environ Anal Toxicol 4: 221. doi: 10.4172/2161-0525.1000221

Copyright: (c) 2014 Nath S, et al. This is an open-access article distributed under the terms of the Creative Commons Attribution License, which permits unrestricted use, distribution, and reproduction in any medium, provided the original author and source are credited. 
the $\sim 1400$ bp sequence were first analyzed by NCBI-BLAST for finding closest homologous sequence. The first ten homologous sequences were selected and were aligned by CLUSTAL X2. Finally, a phylogenetic tree was constructed by MEGA using Neighbour Joining method.

\section{Minimum inhibitory concentration of cadmium of bacterial isolates}

Minimal inhibitory concentrations (MICs) of cadmium and lead for isolated strains were determined by the plate dilution method [13]. MIC was determined against respective heavy metals $\mathrm{Cd}\left(\mathrm{CdCl}_{2}\right)$ and $\mathrm{Pb}\left[\left(\mathrm{CH}_{3} \mathrm{COO}\right)_{2} \mathrm{~Pb} \cdot 3 \mathrm{H}_{2} \mathrm{O}\right]$ by gradually increasing the concentration on Nutrient Agar (NA) plates until the strains failed to give colonies on the plate. The initial concentration used was $50 \mu \mathrm{g} / \mathrm{ml}$ and thereby the concentration was gradually increased by $10-15 \mu \mathrm{g} / \mathrm{ml}$ each time on NA plates. The growth of cultures on last concentration was transferred to the higher concentration by streaking on the plate. MIC was recorded when the isolates failed to grow on plates.

\section{Pot experimental studies}

The bacteria showing the highest MIC were taken under consideration for the preparation of bacterial inoculum. The isolates were inoculated in nutrient broth and kept in shaker incubator at 120 rpm at $28 \pm 2^{\circ} \mathrm{C}$ for 48 hours. After incubation period, $5 \mathrm{ml}$ of broth was added to $45 \mathrm{ml}$ distilled water for the formulation of bio-fertilizer and to carry out the pot experiment.

Seeds of Oryza sativa L. were collected from Krishi Vikas Kendra, Masimpur, Assam. The seed sizes and weights were homogenous. Clean seeds were dipped in water; floating seeds were discarded, while seeds settled on bottom of container were selected. Seeds were surfacesterilized with $95 \%$ alcohol for 30 seconds, followed by $0.1 \%$ (w/v) $\mathrm{HgCl}_{2}$ for 1-2 min and then washed with sterile distilled water for 5-6 times [14]. The seeds were then put in a sterile petridish containing Hogland Solution and remain dipped overnight. The earthen pots $(24 \mathrm{~cm} \mathrm{X} 12$ $\mathrm{cm} X 12 \mathrm{~cm}$ ) were filled with sterilized sandy loam soil. Seeds were sown on all the pots to study the role of bacterial inoculation on seedling growth of Oryza sativa, sown in cadmium and lead incorporated soil. Pot experiments were performed in two different experimental groups and seedling growth of Oryza sativa were recorded after three weeks of exposure heavy metals $(\mathrm{Cd}$ and $\mathrm{Pb})$ and bacterial inoculums.

After performing the pot experiment, SPSS 16.0 was used to analyze the statistical data. Descriptive statistics calculates the means of all replicates with standard error and deviations. Multiple comparison tests were performed to evaluate the effectiveness of each bacterial isolates. When analysis of variance (ANOVA) showed significant effects, Tukey's-b test (assuming equal variances) and Games-Howell test (assuming unequal variances) was done to make comparison between groups at $\mathrm{P}<0.05$ and $\mathrm{P}<0.01$.

\section{Results and Discussions}

\section{Isolation and characterization of bacteria}

Total viable counts ranges from $4.5 \times 10^{4}(\mathrm{CFU} / \mathrm{g})$ in to $20 \mathrm{X} 10^{4}$ (CFU/g). At $1000 \mu \mathrm{g} / \mathrm{ml} \mathrm{CdCl}_{2}$ concentration, resistance to cadmium varies from $48 \%$ to $79.2 \%$. Samples collected from crop field nearby petrol pumps showed the highest frequency for lead tolerant bacteria, showed some resemblance with the work of Bruins et al. [15]. The lower values of microbial load at higher metal concentrations showed correlation with the study of Anyanwu et al. [16].

All the isolates were identified based on their morphological and biochemical characterization [11]. The bacterial isolates identified in this study were mostly Gram-negative, the group that has been often found in metal polluted soils [17-20]. Among all the isolated strains, Ps- 1 and Ps-4 showed the highest tolerance for $\mathrm{Cd}$ and $\mathrm{Pb}$ and hence selected for $16 \mathrm{~S}$ rDNA sequencing. Neighbour-joining tree was constructed using both the sequences i.e., Ps-1 (Figure 1) and Ps-4 (Figure 2) and representative sequences from databases. It has been observed that the strain Ps- 1 and Ps- 4 had maximum sequence similarity with the species of Pseudomonas aeruginosa and occupied the same phylogenetic branch. The 16S rDNA gene sequences of the bacterial isolates were deposited in NCBI-GenBank having accession numbers: KF031122 (Pseudomonas aeruginosa SN1) and KF031123 (Pseudomonas aeruginosa SN3).

\section{Screening for cadmium and lead tolerance}

All the bacterial isolates exhibited high resistance to cadmium with minimum inhibitory concentration (MIC) ranging from $400 \mu \mathrm{g} / \mathrm{ml}$ to $1800 \mu \mathrm{g} / \mathrm{ml}$ (Table 1). In presence of cadmium, P. aeruginosa SN1 and SN3 (coded as Ps-1 and Ps-4 respectively) showed the MIC values as $1700 \mu \mathrm{g} / \mathrm{ml}$ and $1800 \mu \mathrm{g} / \mathrm{ml}$ respectively. P. aeruginosa SN3 exhibited highest MIC for lead as $170 \mu \mathrm{g} / \mathrm{ml}$. The present study suggests that the microorganisms tolerant to metals appear to be the result of exposure to metal contaminated environment, which is fairly consistent with

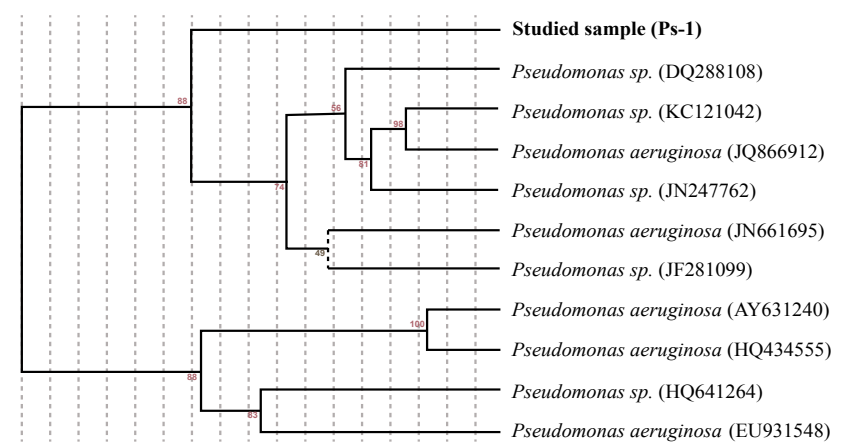

Figure 1: Phylogenetic relationship between studied sample (Ps-1) and representative species based on partial 16S rDNA sequences constructed using the neighbour-joining meth.

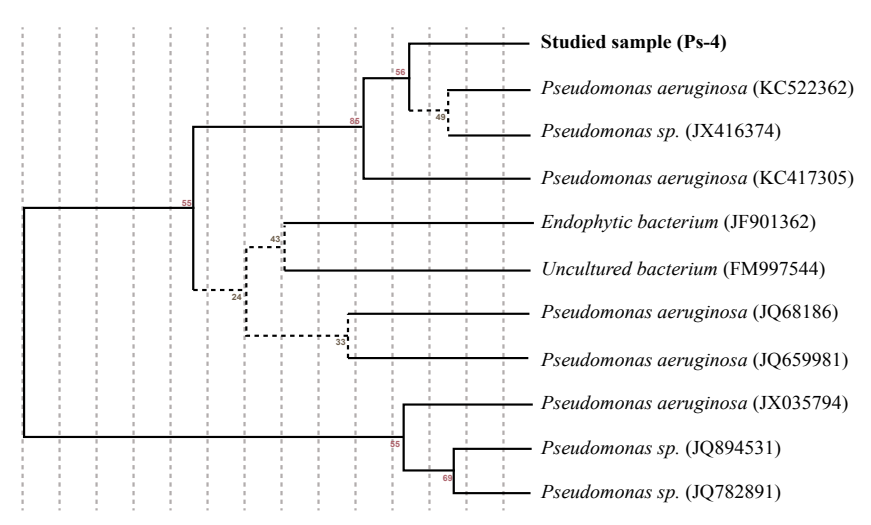

Figure 2: Phylogenetic relationship between studied sample (Ps-4) and representative species based on partial 16S rDNA sequences constructed using the neighbour-joining method. 


\begin{tabular}{|c|c|c|}
\hline \multirow{2}{*}{ Strain No } & \multicolumn{2}{|c|}{ Minimum Inhibitory Concentration } \\
\cline { 2 - 3 } & Cadmium & Lead \\
\hline Ps-1 & $1700 \mu \mathrm{g} / \mathrm{ml}$ & $150 \mu \mathrm{g} / \mathrm{ml}$ \\
\hline Ps-2 & $1100 \mu \mathrm{g} / \mathrm{ml}$ & $80 \mu \mathrm{gl} / \mathrm{ml}$ \\
\hline Ps-3 & $800 \mu \mathrm{g} / \mathrm{ml}$ & $100 \mu \mathrm{gl} / \mathrm{ml}$ \\
\hline Ps-4 & $1800 \mu \mathrm{g} / \mathrm{ml}$ & $170 \mu \mathrm{g} / \mathrm{ml}$ \\
\hline Ps-5 & $1000 \mu \mathrm{gl}$ & $150 \mu \mathrm{ml}$ \\
\hline Ps-6 & $1200 \mu \mathrm{gl} / \mathrm{ml}$ & $160 \mu \mathrm{gl} / \mathrm{ml}$ \\
\hline Ps-7 & $700 \mu \mathrm{g} / \mathrm{ml}$ & $120 \mu \mathrm{m} / \mathrm{ml}$ \\
\hline Ps-8 & $400 \mu \mathrm{gg} / \mathrm{ml}$ & $100 \mu \mathrm{g} / \mathrm{ml}$ \\
\hline
\end{tabular}

Table 1: Minimum inhibitory concentration of bacterial isolates to cadmium and lead.

\begin{tabular}{|c|c|c|c|c|}
\hline \multirow[b]{2}{*}{ Experimental setup } & \multicolumn{2}{|c|}{ Cadmium concentration } & \multicolumn{2}{|c|}{ Lead concentration } \\
\hline & $\underset{\text { soil }}{20 \mathrm{mg} \mathrm{Cd} / \mathrm{kg}}$ & $\begin{array}{l}50 \mathrm{mg} \mathrm{Cd} / \\
\mathrm{kg} \text { soil }\end{array}$ & $\begin{array}{c}20 \mathrm{mg} \mathrm{Pb} / \\
\mathrm{kg} \text { soil }\end{array}$ & $\begin{array}{c}50 \mathrm{mg} \mathrm{Pb} / \\
\mathrm{kg} \text { soil }\end{array}$ \\
\hline $\begin{array}{l}\text { Control (without Cd and } \\
\text { bacteria) }\end{array}$ & $31.66 \pm 0.42$ & $\begin{array}{c}31.66 \pm \\
0.42\end{array}$ & $\begin{array}{c}31.66 \pm \\
0.42\end{array}$ & $\begin{array}{c}31.66 \pm \\
0.42\end{array}$ \\
\hline $\begin{array}{l}\text { Uninoculated control (with } \\
\text { HM only) }\end{array}$ & $27.62 \pm 0.35$ & $\begin{array}{c}25.18 \pm \\
0.26\end{array}$ & $\begin{array}{c}24.56 \pm \\
0.32\end{array}$ & $\begin{array}{c}23.66 \pm \\
0.52\end{array}$ \\
\hline $\begin{array}{l}\text { Inoculation of } P \text {. aeruginosa } \\
\text { SN1 }\end{array}$ & $30.40 \pm 0.30^{*}$ & $\begin{array}{c}29.86 \pm \\
1.33^{*}\end{array}$ & $\begin{array}{c}27.02 \pm \\
0.19^{*}\end{array}$ & $\begin{array}{l}23.26 \pm \\
0.36 \mathrm{~ns}\end{array}$ \\
\hline $\begin{array}{l}\text { Inoculation of } P \text {. aeruginosa } \\
\text { SN3 }\end{array}$ & $\begin{array}{c}26.40 \pm \\
0.86 \mathrm{~ns}\end{array}$ & $\begin{array}{c}22.24 \pm \\
1.63 \mathrm{~ns}\end{array}$ & $\begin{array}{c}28.64 \pm \\
0.32^{*}\end{array}$ & $\begin{array}{l}23.50 \pm \\
0.29 \mathrm{~ns}\end{array}$ \\
\hline
\end{tabular}

Values are mean \pm standard deviation of five replicates; ns $=$ non significant; * $=$ significant at $\mathrm{P}<0.01$; compared with uninoculated control; $\mathrm{HM}$ indicates respective heavy metals, i.e., cadmium and lead

Table 2: Effect of Pseudomonas aeruginosa on seedling growth and germination of Oryza sativa in cadmium and lead incorporated soil.

the findings of Ramteke [21].

Effect of Pseudomonas aeruginosa on seedling growth of Oryza sativa L. inoculated in cadmium incorporated soil

A large number of studies have been already carried out in different crop plants which indicate that, toxic levels of heavy metals affect structural and permeability properties of inner membranes and organelles, cause inhibition of enzymatic activities, nutrient imbalances, decreases in rates of photosynthesis and transpiration $[22,23]$, stimulate formation of free radicals and reactive oxygen species resulting in oxidative stress [24], suppress seed germination and seedling growth [25], reproductive development, seed yield and seed quality [25] and induce deleterious anatomical and ultra-structural changes in crop plants $[26,27]$.

In the present study, inoculation of $P$. aeruginosa SN1 significantly increases cadmium tolerance of Oryza sativa L. at all concentrations of Cd $(20 \mathrm{mg} / \mathrm{kg}$ and $50 \mathrm{mg} / \mathrm{kg})$ in soil. The increased seedling growth by $P$. aeruginosa SN1 having shoot length of $30.40 \pm 0.30 \mathrm{~cm}$ at $50 \mathrm{mg} /$ $\mathrm{kg} \mathrm{Cd}$ in soil was further compared with shoot length of pots without $\mathrm{Cd}$ and bacterial inoculation (Table 2) and the result was found to be consistent with the work of Zhong et al. [28]. The statistical result thus obtained demonstrates $P$. aeruginosa $\mathrm{SN} 1$ as a potent isolate for bioremediation purpose whereas $P$. aeruginosa SN3 showed no significant increase in the seedling growth of rice plant (Table 2). Several studies have evidenced the fact that heavy metal-resistant and plant growth-promoting bacteria can protect plants from the toxic effects of metals [29-31].

After 20 days of seedling inoculation, two strains, $P$. aeruginosa SN1 and $P$. aeruginosa SN3, showed significant result at $20 \mathrm{mg} / \mathrm{kg}$ of lead in soil. However, these isolates do not show any significant response at $50 \mathrm{mg} / \mathrm{kg}$ of lead in soil. Statistical analysis and multiple comparison studies highlight the fact that $P$. aeruginosa SN3 attains $14 \%$ increased seedling growth as compared to uninoculated control pots at $20 \mathrm{mg} / \mathrm{kg}$ $\mathrm{Pb}$ in soil (Table 2). Present study shows some resemblance with the work of Vivas et al. [32], who found that the inoculation of Trifolium repens with Brevibacillus sp. B-I decreased the concentration of zinc in shoot tissues compared with respective uninoculated control. It can be inferred from the above experiment that, metal binding bacteria can reduce the metal bioavailability and restricts its entry into the plant root/shoot Madhaiyan et al. [33].

\section{Conclusion}

Present study demonstrated that $P$. aeruginosa SN1 could increase the growth of Oryza sativa L. in cadmium contaminated field. Both the tested Pseudomonas aeruginosa isolates showed significant result at $20 \mathrm{mg} / \mathrm{kg}$ of lead in soil, but the result was not significant at higher concentration of cadmium in soil. Overall study demonstrated that $P$. aeruginosa $\mathrm{SN} 1$ and $P$. aeruginosa $\mathrm{SN} 3$ could remediate cadmium and lead contaminated soil at concentration below $20 \mathrm{mg} / \mathrm{kg}$, thus dedicating sites which are set aside for long term agricultural purpose.

\section{References}

1. Muchuweti M, Birkett JW, Chinyanga E, Zvauya R, Scrimshaw MD, et al, (2006) Heavy metal content of vegetables irrigated with mixture of wastewater and sewage sludge in Zimbabwe: implications for human health. Agriculture. Ecosystem and Environment 11: 41-48.

2. Gratão PL, Polle A, Lea PJ, Azevedo RA (2005) Making the life of heavy metal stressed plants a little easier. Functl Plant Biol 32: 481-494.

3. Gadd GM (1992) Metals and microorganisms: a problem of definition. FEMS Microbiol Lett 100: 197-204

4. Gadd GM, Griffiths AJ (1978) Microorganisms and heavy metal toxicity. Microb Ecol 4: 303-317.

5. Gadd GM (2004) Microbial influence on metal mobility and application for bioremediation. Geoderma 122: 109-119.

6. Gadd GM (2007) Geomycology: biogeochemical transformations of rocks, minerals, metals and radionuclides by fungi, bioweathering and bioremediation. Mycol Res 111: 3-49.

7. Violante A, Huang PM, Gadd GM (editors) (2008) Biophysicochemical Processes of Heavy Metals and Metalloids in Soil Environments. Chichester: Wiley

8. Ehrlich HL, Newman DK (2009) Geomicrobiology, 5th edn. Boca Raton, FL: CRC Press/Taylor \& Francis.

9. Carrasco JA, Armario P, Pajuelo E, Burgos A, (2005) Isolation and characterisation of symbiotically effective Rhizobium resistant to arsenic and heavy metals after the toxic spill at the Aznalcollar pyrite mine. Soil Biol. Biochem 37: 1131-1140.

10. Ge HW, Lian MF, Wen FZ, Yun YF, Jian FY, et al, (2009) Isolation and characterization of the heavy metal resistant bacteria CCNWRS33-2 isolated from root nodule of Lespedeza cuneata in gold mine tailings in China. J. Hazard Mater 162: 50-56.

11. Krieg NR, Holt JG (1984) Bergey's Manual of Systematic Bacteriology. Vol. 1, eds: Williams and Wilkins. Baltimore.

12. Sambrook J, Russell DW (2001) Molecular Cloning: A Laboratory Manual, 3rd Ed. Cold Spring Harbor Laboratory Press.

13. Aleem A, Isar J, Malik A, (2003) Impact of long-term application of industrial wastewater on the emergence of resistance traits in Azotobacterchroococcum isolated from rhizospheric soil. BioresourTechnol 86: 7-13.

14. Singh N, Pandey P, Dubey RC, Maheshwari DK, (2008) Biological contro of root rot fungus Macrophominaphaseolina and growth enhancement of Pinusroxburghii (Sarg.) by rhizosphere competent Bacillus subtilis BN1. World J MicrobiolBiotechnol 24: 1669-1679.

15. Bruins MR, Kapil S, Oehme FW, (2003) Characterization of a small plasmid 
Citation: Nath S, Deb B, Sharma I, Pandey P (2014) Role of Cadmium and Lead Tolerant Pseudomonas aeruginosa in Seedling Germination of Rice (Oryza sativa L.). J Environ Anal Toxicol 4: 221. doi: 10.4172/2161-0525.1000221

Page 4 of 4

(pMBCP) from bovine Pseudomonas pickettii that confers cadmium resistance. Ecotox. Environ. Safe 54: 241-248.

16. Anyanwu CU, Nwankwo SC, Moneke AN, (2011) Soil Bacterial Response to Introduced Metal Stress. International Journal of Basic \& Applied Sciences 11: 109-115.

17. Kunito T, Shibata S, Matsumoto S, Oyaizu H, (1997) Zinc resistance of Methylobacterium species. Biosci.Biotech.Biochem 61: 729-731.

18. Trojanovska S, Brotz ML, Bhave M, (1997) Detection of heavy metal ion resistance genes in Gram positive and Gram negative bacteria isolated from a lead contaminated site. Biodegradation 8: 113-124.

19. Brim H, Heuer H, Kro"gerrecklenfort E, Mergeay M, Smalla K (1999) Characterization of the bacterial community of a zinc polluted soil. Can $J$ Microbiol 45: 326-338.

20. Kozdroj J, van Elsas JD, (2000) Response of the bacterial community to root exudates in soil polluted with heavy metals assessed by molecular and cultural approaches. Soil Biol Biochem 32: 1405-1417.

21. Ramteke PW (1997) Plasmid mediated co-transfer of antibiotic resistance and heavy metal tolerance in coliforms. Indian J Microbiol 37: 177-181.

22. Green C, Vhaney R, Bouwkamp J (2003) Interactions between cadmium and phytotoxic levels of zinc in hard red spring wheat. J Plant Nutr 26: 417-430.

23. Azevado H, Pinto CGG, Farnandes J, Loureiro S, Santos C, (2005) Cadmium effects on sunflower growth and photosynthesis. J. Plant Nutr 28: 2211-2220.

24. Sandalio LM, Dalurzo HC, Gomez M, Romero-Puertas MC, del Rio LA (2005) Cadmium induced changes in growth and oxidative metabolism of pea plants. $\mathrm{J}$ Expt Bot 52: 2115-2126.

25. Beri A, Setia RC, (1995) Assessment of growth and yield in Lens culinaris Medic. var. masar 9-12 treated with heavy metals under $\mathrm{N}$-supplied conditions.
J Indian Bot. Soc 74: 293-297.

26. Liu D Kottke I, (2004) Subcellular localization of cadmium in root cells of Allium cepa by electron energy loss spectroscopy and cytochemistry. J. Biosci 29 329-335.

27. Maruthi Sridhar BB, Diehl SV, Han FX, Monts DL, Su Y, (2005) Anatomical changes due to uptake and accumulation of $\mathrm{Zn}$ and $\mathrm{Cd}$ in Indian mustard (Brassica juncea). Environ. Expt. Bot 54: 131-141.

28. Zhong W, Yun-Jie GU, Hirasawa T, Ookawa T, Satogo Y (2004) Comparison of caryopsis development between two rice varieties with remarkable difference in grain weight. Acta Botanica Sinica 44: 698-710.

29. Burd GI, Dixon DG, Glick BR, (2000) Plant growth promoting bacteria that decrease heavy metal toxicity in plants. Can J. Microbiol 46: 237-245.

30. Dell'Amico E, Cavalca L, Andreoni V, (2005) Analysis of rhizobacteria communities in perennial Graminaceae from polluted water meadow soil, and screening of metal-resistant, potentially plant growth-promoting bacteria. FEMS Microbiol.Ecol 52: 153-162.

31. Jiang CY, Sheng XF, Qian M, Wang QY, (2008) Isolation and characterization of a heavy metal resistant Burkholderia $\mathrm{sp}$. from heavy metal contaminated paddy field soil and its potential in promoting plant growth and heavy metal accumulation in metal polluted soil. Chemosphere 72:157-164.

32. Vivas A, Biro B, Ruíz-Lozanoa JM, Azcon R (2006) Two bacterial strains isolated from a $\mathrm{Zn}$-polluted soil enhance plant growth and mycorrhizal efficiency under $\mathrm{Zn}$ toxicity. Chemosphere 52: 1523-1533.

33. Madhaiyan M, Poonguzhali S, Sa T (2007) Metal tolerating methylotrophic bacteria reduces nickel and cadmium toxicity and promotes plant growth of tomato (Lycopersicon esculentum L.). Chemosphere 69: 220-228. 